\title{
Stability Analysis of DFIG based Wind Energy System
}

\author{
K. Latha Shenoy ${ }^{\# * * 1}$, C. Gurudas Nayak ${ }^{* 2}$, Rajashekar P Mandi ${ }^{* * 3}$ \\ \# Department of E\&E Engineering, NMAM Institute of Technology, Nitte, Karnataka, India \\ *Dept of Instrumentation \& Control Engg, MIT, MU, Manipal, Karnataka, India \\ ${ }^{*}$ School of Electrical Engineering, REVA University, Bangalore, India \\ ${ }^{1}$ lathashenoy@nitte.edu.in \\ 2 cg.nayak@manipal.edu(corresponding author) \\ 3 rajashekarpm@reva.edu.in
}

\begin{abstract}
This paper presents system stability analysis of DFIG based wind energy conversion system. Presently for variable wind speed DFIG is considered as efficient machine to generate the power. In addition to this advanced AC/DC/AC converters with closed loop control system has been presented. For stability analysis $1.5 \mathrm{MW}$ wind turbine has been considered. As the speed of the wind varies by $\pm 18 \%$ to $20 \%$ the voltage generated will also varies by \pm 18 to $20 \%$. With the aid of precise converter design it is possible to achieve stable output at the grid. From the simulation results it has been found that the method of achieving stable output at the grid is best suitable for wind energy conversion system.
\end{abstract}

Keyword - Wind turbine, wind energy conversion system, power converters, closed loop system, doubly fed induction generator

\section{INTRODUCTION}

Wind energy is one of the major sustainable energy resources. Wind energy is clean and renewable. Wind energy conversion system makes use of modern power electronics knowledge and control [1]. Presently wind energy conversion has attracted worldwide attention for research and development. Therefore, the design of wind turbine is a very popular research area. The DC power produced by renewable energy has to be converted in to AC power by means of modern power electronics and control system. DC power can be converted in to AC power using inverters. Depending upon the mode of operation two types of inverters are required, namely (i) standalone mode inverter and (ii) grid connected inverter. Conversion efficiency is a significant factor for both the types of inverters.

The advancement in technology in designing wind mill blades, wind turbine generators, power electronic converters, and thyristerized control system have provided fast growth for large scale wind power generation [23]. Modern Wind generators incorporate wide range speed control techniques such as blade pitch control or make use of power converters in order to control the output power of the wind turbine. The speed control technique of wind turbine and the grid integration of wind power system is of vital importance, which will be carried out by power electronic devices. Also since the wind speed is uncertain, the power quality and reliability of wind power needs detail evaluation with suitable control schemes. The rapid growth in large scale wind power has made researchers to develop low cost power converters with high power density and reliability. This paper presents modern power converter technology of high power density and reliability as required by the wind energy conversion system.

\section{WIND ENERGY SYSTEM}

The world's environment can be demonstrated as a colossal warmth motor. It removes vitality from one store (the sun) and conveys warmth to another repository at a lower temperature (space). Simultaneously, work is done on the gasses in the air and upon the earth-air limit. There will be areas where the pneumatic stress is incidentally higher or lower than normal. This distinction in gaseous tension causes atmospheric gasses to flow out of the area of higher weight to that of lower weight.

Around 3,850,000 exa joules (EJ) of solar energy per annum is consumed by earth, oceans and the environment. Yearly energy diagram of the same is as appeared in Table I. The whole world's electrical energy is 56.7 EJ, which is less than 1/10,000 accessible solar energy of 3,850,000 EJ. This information demonstrates that sun oriented and wind energy can be adequately utilized and thus necessity of electrical power won't be an issue. 
TABLE 1 Annual Solar Flux and Consumption of Energy

\begin{tabular}{|c|l|l|}
\hline Sl. No & Description & Value \\
\hline 1 & Energy from sun & $3,850,000$ EJ \\
\hline 2 & Wind energy & 2,250 EJ \\
\hline 3 & Biomass energy & 3,000 EJ \\
\hline 4 & Primary energy use & 487 EJ \\
\hline 5 & Electrical energy & 56.7 EJ \\
\hline
\end{tabular}

Wind energy is clean and renewable and in recent times its application has attracted worldwide attention. As a result, the design of wind energy conversion system has become one of the most popular research area. The wind turbine extracts the power from the wind which depends on the following factors.

- Availability of wind power.

- Machine ability to respond to the wind perturbations.

- The characteristics of the machine.

In 1890 first wind energy conversion system was operational in rural USA. Today wind turbine of capacity 1 to $3 \mathrm{MW}$ has been successfully installed worldwide. Also since 1980s capital cost and running costs of wind power technology is reduced by almost $80 \%$ globally, and presently grid integrated wind power generation system has been increased to $95 \%$. As a result, wind power plant has become highly competitive over nonrenewable power plants [4-7]. Table 2 provides evolution in wind power technology.

TABLE 2 Development of wind energy conversion system

\begin{tabular}{|l|l|l|l|l|}
\hline Sl. No & Wind energy details & \multicolumn{1}{|c|}{1980} & \multicolumn{1}{|c|}{1999} & \multicolumn{1}{|c|}{2015} \\
\hline 1. & Power range of wind turbine & $(50-150) \mathrm{KW}$ & $(300-1,000) \mathrm{KW}$ & $(500-3,000) \mathrm{KW}$ \\
\hline 2. & Average capability feature & $15 \%$ & $25 \%$ to $30 \%$ & $>95 \%$ \\
\hline 3. & Life span & 5 to 7 years & 20 years & 30 years \\
\hline 4. & Per KW capital cost & $(2,000-3,000)$ USD & $(500-700)$ USD & $<400$ USD \\
\hline 5. & Per unit cost of energy & $(0.35-0.40)$ USD & $(0.35-0.40)$ USD & $(0.35-0.40)$ USD \\
\hline 6. & Accessibility & 50 to $65 \%$ & $95 \%$ & $>95 \%$ \\
\hline
\end{tabular}

Major features which contributed to the wind energy technology developments are as below.

- Huge low cost blades made up of superior strength fibre amalgam.

- Development of Variable speed wind generators.

- Advancement in microelectronics and control and its cost.

- Improved reliability and efficiency.

- Development of precise system modelling and simulation

Today with the advancements in large low cost blade design, wind generators and power electronics and control it is possible to produce wind power in large scale. The advancement in microelectronics and control is of essential significance for the innovation of wind energy conversion system. In particular speed control of the wind turbines and grid interfacing is of major importance. Presently, blade pitch control or power converter inversion technology has been incorporated by the wind generators to adjust the power output of the variable speed of the wind turbines [8-12]. Because the wind speed is fluctuating, the reliability and quality of the wind power requires detail evaluation and for power conditioning suitable control schemes are to be adopted. Types of wind power systems are standalone, hybrid and grid connected.

\section{DESIGN CONCEPT OF WIND ENERGY SYSTEM}

The wind turbine which produces the mechanical power, a cubic function of wind speed is given by

$$
P_{m}=0.5 C_{p} A V^{3} \rho
$$

Where power coefficient $=\mathrm{C}_{\mathrm{p}}$,

Area swept by rotor of the wind turbine, $\mathrm{m}^{2}=\mathrm{A}$,

Speed of the wind, $\mathrm{m} / \mathrm{s}=\mathrm{U}$.

The dynamic efficiency of the rotor is calculated by means of suitable expression for $\mathrm{C}_{\mathrm{p}}$ with a function of pitch angle for variable speed wind turbine. 
The power coefficient $C_{p}$ is the ratio of power available at the shaft to the available wind power which is given by

$$
C_{p}=\frac{P_{m}}{0.5 \rho A V^{3}}
$$

Power curve of the wind turbine is as shown in figure 1. The power generated by wind turbine doubles as the area swept by wind mill blade doubles. Therefore, as the wind speed doubles, output power will increment by eight times.

The figure 2 shows different power curves of a wind turbine [13-18]. At various wind speeds, if the operating point is along the maximum power locus, which will be carried out by controlling the load on the wind turbine, then the wind energy system will be highly efficient. Figure 3 shows production of wind.

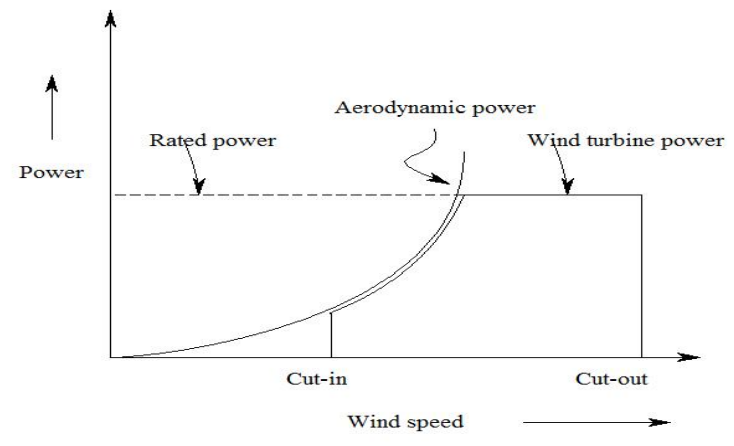

Fig 1: Wind turbine power curve

The wind speed is disturbed and is represented as the Weibull probability density function as shown in Equation (3) and Figure 4 shows Weibull probability function.

$$
f(v)=\frac{k}{c}\left(\frac{v}{c}\right)^{k-1} e^{-\left(\frac{v}{c}\right)^{2}}
$$

Where $\mathrm{k}=$ shape parameter,

$\mathrm{v}=$ wind speed and $\mathrm{c}=$ scale parameter.

The air stream through the wind turbine is given by

$m=A_{1} v=A v_{b}=A_{2} v_{d}$

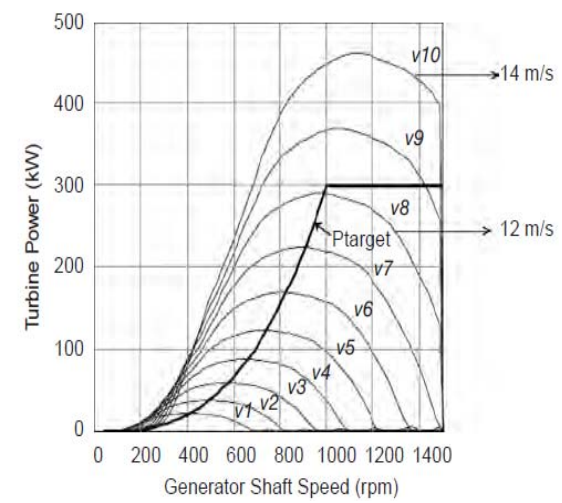

Fig 2: Turbine power vs. generator shaft speed curves

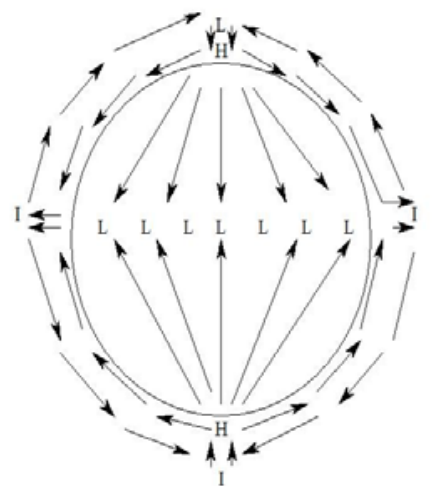

Fig 3: Wind production

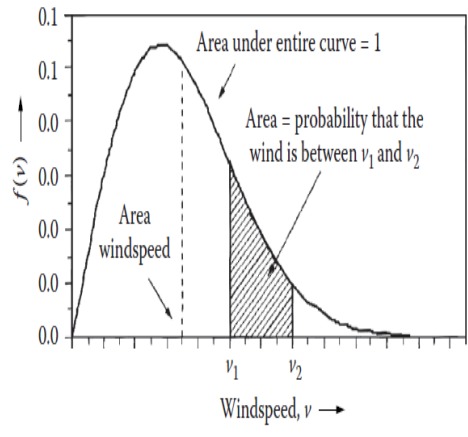

Fig 4: Weibull probability density function

Figure 3 shows the air flow through the wind turbine. The power drawn by the wind turbine is given by

$$
P=\frac{1}{2} m\left(v^{2}-v_{d}^{2}\right)
$$




$$
\begin{gathered}
v_{b} \approx \frac{1}{2}\left(v+v_{d}\right) \\
P=\frac{1}{2} m\left(v^{2}-v_{d}^{2}\right) \\
P=0.5 \rho A V^{3}\left[\frac{1}{2}(1+\lambda)\left(1-\lambda^{2}\right)\right]
\end{gathered}
$$

Since $m=\rho A v_{b}$

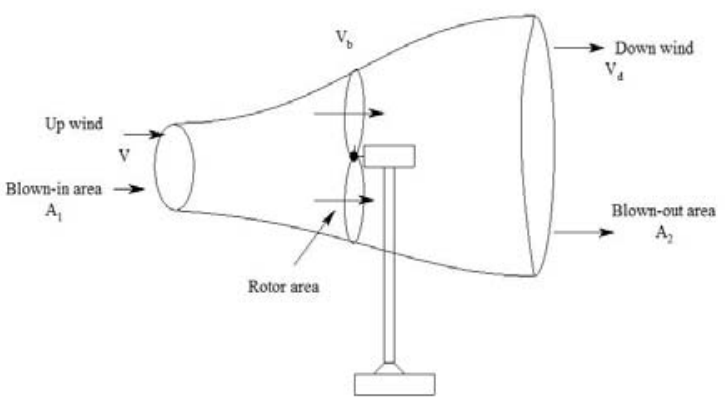

Fig 5: Air stream through the wind turbine

Where,

$\rho=$ air density

$\mathrm{A}=$ rotor area

$\mathrm{v}_{\mathrm{b}}=$ turbine wind speed

$\mathrm{v}=$ inlet wind speed

$\mathrm{v}_{\mathrm{d}}=$ blow-out wind speed.

According Betz's law wind power is given by

$$
P=0.5 \rho \Pi R^{2} v^{3} C_{p}
$$

here $\mathrm{R}=$ radius of the windmill.

The air density is given by

$$
\rho=353 \frac{P}{T}
$$

The unit of $\rho$ is $\mathrm{kg} / \mathrm{m}^{3}$.

\section{IV.GENERATORS FOR WIND SYSTEM}

Induction Generators and Permanent Magnet Synchronous Generators (PMSG) are generally used for wind energy applications. This is because of their simplicity in construction, low maintenance, ruggedness and cost effectiveness. For fixed speed operation, wind turbine with synchronous generators is used, which can operate at any power factor. Whereas wind turbine with induction generators will supply only active power and at the same time it consumes the reactive power. Considering the similar size and high power rating, the synchronous generators are more expensive than induction generators. Also for grid connected applications, synchronous generators are connected through the power converters to the grid. There are various methods to operate the Variable Speed Wind Turbine (VSWT). One among them is dynamic slip control which uses doubly-fed induction generators (DFIG). But for operation of DFIG reactive power is required. A gear box is necessary for the wind turbine which makes use of induction generators. But the drawbacks are more cost, extra losses and regular maintenance.

- A wound rotor induction generator with rotor side control is useful for large scale wind power generation, because of variable speed constant frequency (VSCF) operation. The advantages of wound rotor induction generators for VSCF are Enhanced wind energy capture.

- Without any modifications of construction, there will be increase in shaft power of the induction generator.

- Turbulent wind energy can be captured by a variable speed turbine. 
- Superior grid quality and efficient operation.

Figure 6 shows the block diagram of the wind power system. Advancement in power electronics and control is of vital importance for implementing variable speed operation. It is because of this technology wind energy conversion system has made a significant advancement. In order to meet the requirements of the present power generating systems, the know-how of power electronics has to be developed right from the devices to the system network. The requirements of advances are as listed as below.

- Modular type power converters. Modular system with high power density will offer flexibility and efficiency for high power wind generation systems.

- The requirement of integration of other renewable energy sources like photovoltaic and fuel cell with cooling technologies are to be dealt with.

- Incorporating new superior switching technology with enhanced temperature capability.

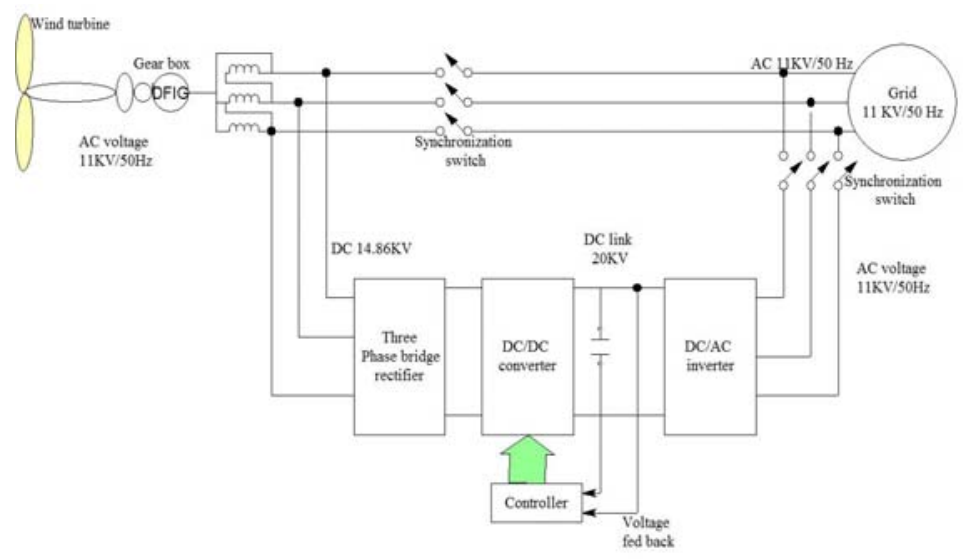

Figure 6: Configuration of the wind turbine power system

\section{ILLUSTRATION OF WIND ENERGY CONVERSION SYSTEM}

The detail technical specifications of wind power system are shown in Table 3.

The following parameters have been calculated for the above technical specification.

TABLE 3 Wind generator parameter calculation

\begin{tabular}{|c|l|l|l|}
\hline Sl No & \multicolumn{1}{|c|}{ Description } & \multicolumn{1}{c|}{ Values } & \multicolumn{1}{c|}{ Units } \\
\hline 1. & Slip of generator & 0.05 & -- \\
\hline 2. & $\begin{array}{l}\text { Mechanical power converted } \\
\text { into electrical power }\end{array}$ & 465.54 & $\mathrm{KW}$ \\
\hline 3. & $\begin{array}{l}\text { Rotor injected voltage using } \\
\text { turns ratio }\end{array}$ & $\begin{array}{l}\mathrm{V}_{1}=\frac{1}{3} v_{2} \\
335 \angle-8.57^{\circ}\end{array}$ & Volts \\
\hline 4. & $\begin{array}{l}\text { Frequency of the rotor injected } \\
\text { voltage }\end{array}$ & $\begin{array}{l}f_{2}=s f_{1} \\
0.05 * 50=2.5\end{array}$ & $\mathrm{~Hz}$ \\
\hline 5. & $\begin{array}{l}\text { Real power absorbed by rotor } \\
\text { converter } P_{r}\end{array}$ & -46.6 & $\mathrm{KW}$ \\
\hline 6. & Reactive power injected, Qr & 8.25 & $\mathrm{KVAR}$ \\
\hline 7. & $\begin{array}{l}\text { Real power drawn from the } \\
\text { grid }\end{array}$ & -443.442 & $\mathrm{KW}$ \\
\hline
\end{tabular}


TABLE 4 Details of wind power system

\begin{tabular}{|l|l|l|l|}
\hline Technical details & Specifications & Technical details & Specifications \\
\hline Turbine type & Horizontal-axis & No. of blades & 2-blade system \\
\hline Diameter & 50 Meter & Height of the tower & 70 Meter \\
\hline Efficiency of turbine & $45 \%$ & Efficiency of gearbox & $85 \%$ \\
\hline Speed ratio & 65 & Induction generator Type & Wound rotor \\
\hline No. of phases & Three phase & No. of poles & Four pole \\
\hline Type of winding & Delta connected & $\begin{array}{l}\text { Voltage and frequency } \\
11 \mathrm{kV} \text { and 50Hz. }\end{array}$ & \\
\hline Mode of operation & Slip-power control & $\begin{array}{l}\text { Stator per phase } \\
\text { magnetizing inductance }\end{array}$ & $7 \mathrm{H}$ \\
\hline $\begin{array}{l}\text { Rotor resistance } \\
\mathrm{I}_{\mathrm{r}} \text { (stator referred) }\end{array}$ & $30 \Omega$ & Turns ratio, $\mathrm{N}_{\mathrm{s}} / \mathrm{N}_{\mathrm{r}}$ & $3: 1$ \\
\hline $\begin{array}{l}\text { Grid } \\
\text { Temperature7.79 m/s Wind } \\
\text { speed }\end{array}$ & $3-$ phase, $11 \mathrm{kV}, 50$ & Height & $\begin{array}{l}500 \text { meter above } \\
\text { sea level }\end{array}$ \\
\hline
\end{tabular}

\section{DESIGN OF POWER CONVERTERS}

The following conditions are considered for designing power converters for wind energy system.

- The unstable wind speed which will change at certain interval of time at certain speed range.

- The variations in output voltage and frequency of DFIG by $\pm 20 \%$.

This unstable wind energy is converted into electrical energy and delivered to the grid. The design parameters of power converters for the above conditions are shown in Table 4.

TABLE 5 Parameters of the wind energy power converters.

\begin{tabular}{|l|l|l|}
\hline Sl.No & \multicolumn{1}{|c|}{ Description } & \multicolumn{1}{|c|}{ Values } \\
\hline 1 & Output voltage, $\mathrm{V}_{\mathrm{LL}(\mathrm{rms})}$ of DFIG & $11 \mathrm{kV}$ \\
\hline 2 & Frequency of DFIG & $50 \mathrm{~Hz} \pm 20 \%$ \\
\hline 3 & Grid voltage \& frequency & $11 \mathrm{kV}$ and $50 \mathrm{~Hz} \pm 1 \%$ \\
\hline 4 & AC/DC rectifier & $\begin{array}{l}\text { Full bridge diode rectifier with unstable output } \\
\text { voltage } 14.86 \mathrm{kV} \pm 20 \% .\end{array}$ \\
\hline 5 & DC/DC converter & $\begin{array}{l}\text { Closed loop Boost converter with stable output } \\
\text { voltage } 20 \mathrm{kV} \pm 1 \%\end{array}$ \\
\hline 6 & DC/AC inverter & 3-phase, $50 \mathrm{~Hz}, 11 \mathrm{kV}$ Voltage Source Inverter \\
\hline
\end{tabular}

VII. SIMULATION RESULS

Simulation results are shown in figures $7 \mathrm{a}, 7 \mathrm{~b}$, and $7 \mathrm{c}$ respectively. It is shown that when the input voltage and frequency are changed by $\pm 20 \%$, both output voltage and frequency of the system remained stable.
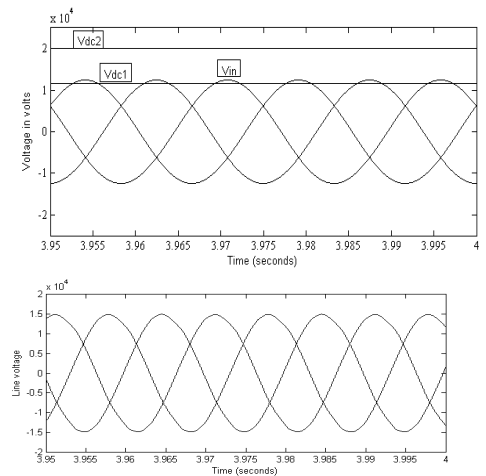

Fig 7a:Line to line Input voltage of $8.8 \mathrm{kV}$ at $40 \mathrm{~Hz}$

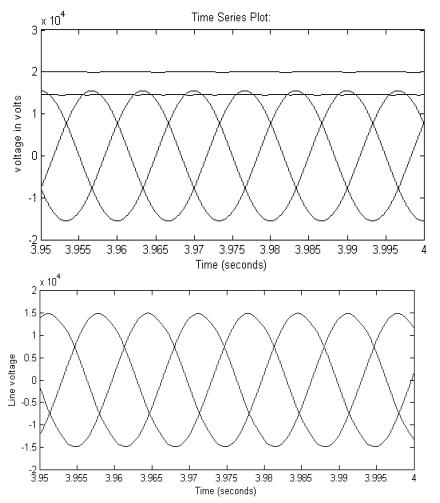

Fig 7b: Line to line Input voltage of $11 \mathrm{kV}$ at $50 \mathrm{~Hz}$

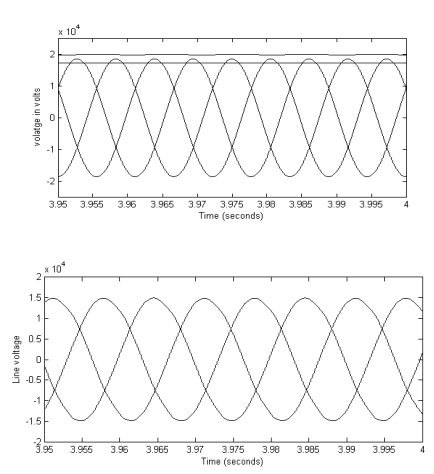

Fig 7c: Line to line Input voltage of $13.2 \mathrm{kV}$ at $60 \mathrm{~Hz}$ 


\section{CONCLUSION}

The proposed wind energy conversion system with doubly fed induction generator is capable of achieving high power density, enhanced efficiency and reliability. It is found that design configuration with performance requirements of the power converters are capable to achieve stable output voltage and frequency when the wind speed is varied at different intervals of time.

\section{REFERENCES}

[1] R. D. Richardson and G. M. McNerney, "Wind energy systems,"Proceedings of the IEEE, vol. 81, pp. 378-389, 1993

[2] S. S. Murthy, B. Singh, P. K. Goel, and S. K. Tiwari, "A comparative study of fixed speed and variable speed wind energy conversion systems feeding the grid," in Proc. Int. Conf. on Power Electronics

[3] Vijay Chand Ganti, Bhim Singh, Fellow, IEEE, Shiv Kumar Aggarwal, and Tara Chandra Kandpal, "DFIG-Based Wind Power Conversion With Grid Power Leveling for Reduced Gusts" IEEE Transactions on Sustainable Energy, vol. 3, no. 1, january 2012 IEEE Trans. Power Electron., vol. 10, no. 4, pp. 472-478, Jul. 1995.

[4] A. Miller, E. Muljadi, and D. Zinger, "A variable speed wind turbine power control," IEEE Trans. Energy Convers., vol. 12, no. 2, pp.181-186, Jun. 1997.

[5] C. V. Nayar, J. Perahia, and F. Thomas., "Small scale wind poweredelectrical generators," The Minerals and Energy Research Institute of Western Australia, 1992.

[6] I. Boldea, Variable Speed Generators. New York: CRC Press, Taylor \& Francis, 2006

[7] C. V. Nayar, J. Perahia, F. Thomas, S. J. Phillips, T. L. Pryor, and W. L. James, "Investigation of capacitor excited induction generators and permanent magnet alternators for small scale wind power.

[8] S. Peresada, A. Tilli, and A. Tonielli, "Robust active-reactive powercontrol of a doubly-fed induction generator," presented at IECON_98, 1998.

[9] A. Chattopadhyay, "An adjustable-speed induction motor drive witha thyristor-commutator in the rotor," IEEE Trans. Ind. Appl., vol. 14,pp. 116-122, 1978X.G.Wu, J. B. Ekanayake, andN. Jenkins, "Comparison of fixed speedand doubly-fed induction wind turbines during power system disturbances,"in Proc. Inst. Elect. Eng., Generation, Transmission and Distribution,

[10] P. Pena, J. C. Clare, and G. M. Asher, "Doubly fed induction generatorusing back-to-back PWM converters and its application to variable speed wind-energy generation," IEE Proceedings Electric Power Applications, vol. 143, 1996

[11] H. Azaza, "On the dynamic and steady state performances of a vectorcontrolled DFM drive," presented at IEEE International Conference on Systems, Man and Cybernetics, 2002.

[12] Y. Tang and L. Xu, "A flexible active and reactive power control strategy for a variable speed constant frequency generating system,"

[13] F. Blaabjerg, Z. Chen, and S. B. Kjaer, "Power electronics as efficient interface in dispersed power generation systems," IEEE Trans. On Power Electronics, vol. 19, pp. 1184-1194, 2004.

[14] J. Wilkie, W. E. Leithead, and C. Anderson, "Modelling of wind turbines by simple models," Wind Engineering, vol. 14, pp. 247273,1990 .

[15] F. Blaahjerg, Z. Chen, and P. H. Madsen, "Wind power technologystatus, development and trends," presented at Proc. Workshop on Wind Power and Impacts on Power Systems, Oslo, Norway, 2002.

[16] E. Muljadi and C. P. Butterfield, "Pitch-controlled variable-speed wind turbine generation," IEEE Transactions on Industry Applications,vol. 37, no. 1, pp. 240-246, Jan/Feb 2001.

[17] A. B. Raju, "Application of power electronic interfaces for gridconnected variable speed wind energy conversion systems," in Department of Electrical Engineering. Bombay: Indian Institute ofTechnology, 2005.

\section{AUTHOR PROFILE}

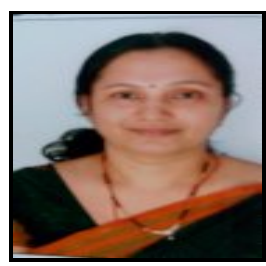

K.Latha Shenoy is currently working as assistant professor in the department of Electrical \& Electronics engineering at NMAM Institute of Technology, Nitte. She received her B.E. degree in the year 1996 from Mangalore University. She has 13 years of teaching experience and 4 years of industrial experience. She received M.Tech degree in digital Electronics and Advanced communication from Manipal Institue of Technology, Manipal. Her research interests includes renewable energy systems, power electronics, control systems.

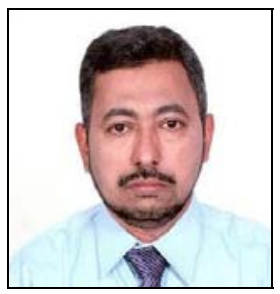

Dr.C. Gurudas Nayak, received his B.E. in Instrumentation Technology in 1988 from Gulbarga University, Gulbarga India and M.S. in Communication Engineering in the year 1996 from NewPort University, USA and PhD from Manipal University, Manipal, India in the year 2008. He has 28 years of Industrial/teaching experiences and published 76 papers in International, National Conferences and journals. He is currently working as a Professor in the Instrumentation and Control Engineering department, Manipal Institute of Technology,Manipal University, Manipal. His research interests include Communication Networks, Instrumentation and Transducers and Mobile Telephone Systems 


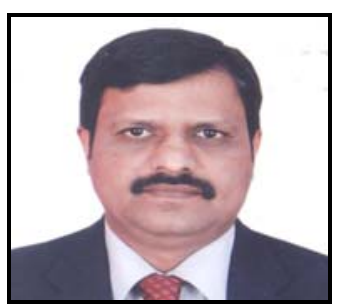

Dr. Rajashekar P. Mandi is presently working as Director of School of Electrical Engineering, REVA University, Bangalore. Before joining REVA University, he worked in Central Power Research Institute, Bangalore for more than 26 years in research. He received M. Tech. degree in Energy Systems Engineering from Visweswaraiah Technological University, Belgaum with $3^{\text {rd }}$ rank and Ph.D in Power and Energy from NITK, Surathkal through research. He is a professional member of IEEE. He is accredited energy auditor from Bureau of Energy Efficiency (BEE), Govt. of India. He is presently chairman of Society for Energy Efficiency \& Manager (SEEM) Karnataka Chapter 